\title{
JEDEN Z HEREZJARCHÓW? \\ PRZEDSTAWIENIA IKONOGRAFICZNE MAHOMETA W RĘKOPISIE PHБ, F.IV.151 W KONTEKŚCIE STARORUSKICH NARRACJI NA JEGO TEMAT ${ }^{* *}$
}

1. Лицевой летописный свод - specyfika formalna źródła. Rękopis РНБ, F.IV.151 stanowi trzeci tom niezwykle bogato ilustrowanej staroruskiej kompilacji historiograficznej (znanej w literaturze przedmiotu jako Лицевой летописный свод сzy też Лицевой свод) $)^{1}$, sporządzonej w jednym odpisie dla cara Iwana IV Groźnego (1533-1584), na potrzeby jego księgozbioru. Borys M. Kloss, poddawszy gruntownej analizie kodykologicznej i paleograficznej wszystkie części zabytku i skonfrontowawszy wyniki swoich badań z ustaleniami historyków na temat okoliczności jego powstania, skłonny jest przyjąć, iż Лииевой свод spisywany był w latach 1568-1576 przez zamknięty zespół skrybów i artystów-miniaturzystów, zatrudnionych w skryptorium działającym przy katedralnej cerkwi Opieki Matki Bożej, w ówczesnej siedzibie ruskiego władcy: Słobodzie Aleksandrowskiej².

Kompilacja, powstała w najmroczniejszym okresie rządów cara Iwana IV Groźnego, kojarzonym przede wszystkim z terrorem opryczniny, obejmuje obecnie dziesięć obszernych (ok. 1000 kart) rękopiśmiennych tomów. Kompleksowe badania nad nią utrudnia fakt, iż została ongiś rozdzielona pomiędzy trzy księgozbiory: bibliotekę Rosyjskiej Akademii Nauk w St. Petersburgu (БАH, 3 rękopisy); Rosyjską Bibliotekę Narodową w St. Petersburgu

* Dr Zofia A. Brzozowska - adiunkt naukowy w Katedrze Filologii Słowiańskiej na Wydziale Filologicznym Uniwersytetu Łódzkiego; e-mail: zofia.brzozowska@uni.lodz.pl.

** Niniejszy artykuł powstał w ramach projektu sfinansowanego ze środków Narodowego Centrum Nauki, przyznanych na podstawie decyzji nr DEC-2016/23/B/HS3/01891 (Mahomet i narodziny islamu - stereotypy, wiedza i wyobrażenia w kręgu kultury bizantyńsko-ruskiej).

${ }^{1}$ Przyjęta w historiografii nazwa nawiązuje do specyfiki formalnej kompilacji, tj. do jej ilustracyjno-tekstowego charakteru. W polskojęzycznej literaturze przedmiotu określa się ją niekiedy terminem Iluminowany zwód latopisarski, por. H. Grala, Wygrać klęskę: pamięć „, wielkiej bitwy" w oficjalnej narracji moskiewskiej (XVI w.), w: Bitwa pod Orsza, red. M. Nagielski, Warszawa 2016, 237-238.

2 Por. Б.М. Клосс, Никоновский свод и русские летописи XVI-XVII вв., Москва 1980, 206-249. 
(РНБ, 4 rękopisy) oraz Państwowe Muzeum Historyczne w Moskwie (ГИМ, 3 rękopisy) $)^{3}$.

Лицевой летописный свод prezentuje rozwój państwowości ruskiej na szerokim tle historii powszechnej. Zawiera, pomieszczony na kartach trzech rękopisów (ГИМ, Музейск. собр. 358; БАН, 17.17.9; РНБ, F.IV.151), dość syntetyczny wykład dziejów uniwersalnych, poczynając od stworzenia świata, przez wydarzenia opisane w Starym Testamencie, historię starożytnej Grecji, państw hellenistycznych, republiki i cesarstwa rzymskiego, aż po zarys dziejów Bizancjum (wraz z dość obszernymi dygresjami na temat Bułgarii), doprowadzony do początku X stulecia. Kolejne tomy (РНБ, F.IV.225; РНБ, F.IV.233; БАН, 31.7.30; РНБ, F.IV.232; ГИМ, Синод. собр., 962; ГИМ, Синод. собр., 149) ukazują historię Rusi od 1114 r. do roku 1567, tj. czasów współczesnych autorom zwodu ${ }^{4}$.

Już pobieżny przegląd zawartości omawianego tu zabytku pozwala na wychwycenie interesującej lacuny w jego treści: o ile narracja na temat dziejów Bizancjum i Bułgarii urywa się dość niespodziewanie w 919 r., o tyle historia Rusi rozpoczyna się od opisu wypadków z drugiej dekady XII w., a zatem od momentu, do którego doprowadzono tekst Powieści minionych lat. Niektórzy badacze skłonni są zatem przypuszczać, że pierwotnie w obręb kompilacji wchodził także tom, ukazujący początki państwowości ruskiej, który nie zachował się jednak do czasów obecnych ${ }^{5}$. Do naszych dni nie dotrwała też zapewne ostatnia część dzieła, prezentująca wydarzenia z 1568 r. Warto również nadmienić, że Лицевой свод jest przedsięwzięciem nieukończonym - prace nad nim, z niewyjaśnionych do końca przyczyn (być może, wskutek niezadowolenia cara z zawartości wcześniejszych tomów) zarzucono ${ }^{6}$.

Można natomiast przypuszczać, że doprowadzenie wykładu historii powszechnej do tej epoki, w której ukształtowało się państwo ruskie, było świadomym zamierzeniem twórców kompilacji, pragnących ukazać swoją ojczyznę jako swoistego sukcesora dawnych imperiów, przede wszystkim cesarstwa rzymskiego i bizantyńskiego.

Лицевой летописный свод słusznie uchodzi w kręgu specjalistów za zjawisko bez precedensu $\mathrm{w}$ dziejach średniowiecznej historiografii ruskiej. Jest bodaj jedynym (obok manuskryptu РГБ, f. 173.100, zawierającego tekst

\footnotetext{
${ }^{3}$ Por. tamże, s. 206; tenże, Летописный свод лицевой, w: Словарь книжников и книжности Древней Руси (вторая половина XIV-XVI в.), ред. Д.С. Лихачев, t. 2, Ленинград 1989, 30; А.А. Амосов, Лицевой летописный свод Ивана Грозного. Комплексное кодикологическое исследование, Москва 1998, 13-16; Лицевой летописный свод ХVI в. Методика описания и изучения разрозненного летописного комплекса, ред. Е.А. Белоконь - В.В. Морозов - С.А. Морозов, Москва 2003, 15-23; В.В. Морозов, Лииевой свод в контексте отечественного летописания XVI в., Москва 2005, 12-19.

${ }^{4}$ Por. Амосов, Лицевой летописный свод, s. 13-16; Лицевой летописный свод, s. 15-23; Морозов, Лииевой свод, s. 12-19.

${ }^{5}$ Por. Клосс, Никоновский свод, s. 207 і 214; tenże, Летописный свод лицевой, s. 30.

${ }^{6}$ Por. Клосс, Никоновский свод, s. 265; tenże, Летописный свод лицевой, s. 30-31.
} 
słowiańskiego przekładu kroniki Jerzego Mnicha (Hamartolosa) oraz XV-wiecznego, iluminowanego odpisu Powieści minionych lat, tzw. Latopisu Radziwiłłowskiego) zabytkiem, prezentującym wydarzenia z przeszłości paralelnie za pomocą słowa i obrazu, tekstu i ilustracji ${ }^{7}$. W każdym z dziesięciu wspomnianych wyżej rękopisów nieomal wszystkie karty ozdobiono miniaturami. Zazwyczaj iluminacja zajmuje $2 / 3$ strony, a tekst tylko 1/3. Jak podkreślają znawcy zagadnienia, pracę nad kompilacją zorganizowano w taki sposób, by - dzięki ścisłemu współdziałaniu pisarzy i artystów - osiągnać najpełniejszą synchronizację warstwy tekstowej z wizualną. Przeznaczony do włączenia w obręb zwodu fragment narracji dzielono najprawdopodobniej na segmenty, które rozmieszczano na danej karcie. Kiedy kopista zakończył już pracę nad nią, trafiała ona w ręce iluminatora, którego zadaniem było sporządzenie - na pozostawionej mu do dyspozycji przestrzeni - miniatur, możliwie najwierniej ilustrujących znajdujący się na obu stronach tekst ${ }^{8}$. Artyści byli też, co ciekawe, zobligowani do zachowania określonego porządku, pracując nad kompozycją poszczególnych scen: wydarzenia, opisane na początku danego segmentu tekstu, winny zostać wyobrażone w górnej części miniatury, zaś te następujące po nich, w niższej partii przedstawienia. Kwestią drugorzędną były natomiast związki przyczynowo-skutkowe, zachodzące między ukazanymi wypadkami: nierzadko na jednej miniaturze przedstawiano kilka zgoła odrębnych scen ${ }^{9}$.

W tym miejscu warto również poświęcić choć kilka słów źródłom, w oparciu o które skompilowano Лицевой летописный свод. Jak wykazały badania rosyjskich uczonych, część dzieła, poświęcona historii Rusi, bazuje na utworach proweniencji wschodniosłowiańskiej, przede wszystkim zaś na Latopisie Nikonowskim, wielotomowym zabytku historiografii moskiewskiej, powstałym w latach pięćdziesiątych XVI w. Podstawą wykładu dziejów powszechnych był natomiast głównie Latopis helleński i rzymski drugiej redakcji (z 1. poł. XV w.) oraz, w mniejszym stopniu, Chronograf ruski z 1512 r. Dwa ostatnie źródła są natomiast zależne od tekstów bizantyńskich, znanych w (staro)-cerkiewno-słowiańskim przekładzie: kronik Jana Malalasa, Jerzego Mnicha (Hamartolosa) wraz z jej anonimową kontynuacja, Jana Zonarasa i Konstantyna Manassesa ${ }^{10}$.

${ }^{7}$ Por. А.В. Арциховский, Древнерусские миниатюры как исторический источник, Москва 1944, 4-40; О.И. Подобедова, Миниатюры русских исторических рукописей, Москва 1965, 11 101; O.S. Popova, Altrussische Buchmalerei 11. bis Anfang 16. Jahrhundert, Leningrad 1984, tabl. 17; О.Г. Ульянов, Изучение семантики древнерусской миниатюры, w: Макариевские чтения, t. 4/2: Почитание святых на Руси, Можайск 1996, 108-119.

${ }^{8}$ Por. Амосов, Лицевой летописный свод, s. 226 і 234; Морозов, Лицевой свод, s. 207.

9 Por. В.Д. Черный, Некоторые особенности обозначения исторической среды в миниатюрах лицевого летописного свода ХVI в. (география, топография, архитектура), w: Государственные музеи Московского Кремля. Материалы и исследования. Новые атрибуиии, t. 5, Москва 1987, 69; Амосов, Лицевой летописный свод, s. 230.

${ }^{10}$ Por. О.В. Творогов, О составе и источниках хронографических статей Лицевого свода, 
2. Mahomet na kartach rękopisu РНБ, F.IV.151 - aspekty wizualne. Rękopis РНБ, F.IV.151 (znany w literaturze przedmiotu jako Лицевой хронограф) jest kodeksem papierowym, obejmującym 1217 kart o wymiarach 40 x $30 \mathrm{~cm}$, w oprawie z XVIII w. Jego treść ilustruje 2191 miniatur. Tom zawiera opis dziejów cesarstwa rzymskiego od lat siedemdziesiątych I w. po Chr. do czasu panowania Konstantyna I Wielkiego (306-337), a następnie wykład historii Bizancjum do roku 919. Tekst urywa się w trakcie narracji na temat przejmowania władzy cesarskiej przez Romana I Lekapena (920-944) ${ }^{11}$.

$\mathrm{Na}$ kartach 677-681' odnajdujemy obszerną sekwencję poświęconą Mahometowi (ok. 570-632), zatytułowaną znacząco $W$ Бохмитє єрєтиц' $(O \text { Bohmicie heretyku })^{12}$. Nie możemy jej niestety uznać za oryginalny utwór staroruski. Nawet pobieżna lektura interesującego nas tu tekstu pozwala bowiem stwierdzić, iż stanowi on de facto przeredagowaną wersję dedykowanego założycielowi islamu fragmentu kroniki Jerzego Mnicha. Twórcy trzeciego tomu Iluminowanego zwodu latopisarskiego nie zaczerpnęli jej jednak bezpośrednio ze staro-cerkiewno-słowiańskiego przekładu dzieła Hamartolosa, lecz z bazującego na nim Latopisu helleńskiego i rzymskiego drugiej redakcji ${ }^{13}$. Treść tego ostatniego zabytku stała się również podstawą dalszej partii narracji (fol. 682-688'), zawierającej informacje o śmierci muzułmańskiego proroka i opis, rozpoczętych rychło po niej, najazdów arabskich na wschodnie tereny cesarstwa bizantyńskiego, w trakcie których

„Труды Отдела древнерусской литературы” 28 (1974) 353-364; Клосс, Никоновский свод, s. 206; tenże, Летописный свод лицевой, s. 31-32; В.В. Морозов, От Никоновской летописи $\kappa$ Лицевому летописному своду. Развитие жанра и эволючия концепщии, „Труды отдела древнерусской литературы” 44 (1990) 246-268; Амосов, Лицевой летописный свод, s. 304-314.

${ }^{11}$ Рог. Амосов, Лицевой летописный свод, s. 13; Лицевой летописный свод, s. 16; Морозов, Лицевой свод, s. 13.

12 Por. Лицевой летописный свод XVI в. Всемирная история, ред. Х.Х. Мустафин, t. 8, Москва 2014, 389-398. W tekstach staroruskich zauważa się brak jednej, zwyczajowo przyjętej formy imienia Mahometa. W utworach tych odnaleźć można wiele różnych wariantów. Niektóre z nich są dość popularne: Махмєтъ (subwarianty: Махъметъ, Мдгмєтъ) oraz Бохмитъ (subwarianty: Бохъмитъ, Бохмєтъ, Бахмєтъ), inne zaś występują o wiele rzadziej (Мухумєтъ / Мухамєтъ;

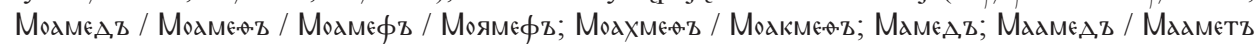

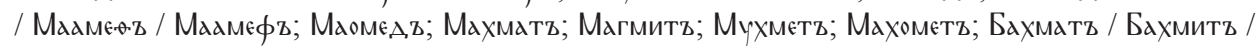
Бехмєтъ / Богмитъ / Богъмєтъ). Istnieją też formy, których pojawienie się należy wiązać z błędem kopisty, np. Модиєа, / Иодиєа, Z; Боихъметъ / Хмитъ). Warianty te były przez średniowiecznych autorów ruskich używane wymiennie. Niekiedy w tym samym tekście pojawia się obok siebie kilka odmiennych form. Fenomenowi temu oraz próbie wyjaśnienia jego genezy poświęciłam odrębny artykuł: Z.A. Brzozowska, Махметь, Мухуметъ, Моамедъ, Бохмитъ. Formy imienia Mahometa w średniowiecznych tekstach ruskich (XI-XVI w.) i ich pochodzenie, „Die Welt der Slaven. Sammelbände" [w druku].

${ }^{13}$ Por. Летописеи Еллинский и Римский, ред. О.В. Творогов, t. 1, Санкт-Петербург 1999, 402-405. Zob. Творогов, O составе, s. 356; P. Bushkovitch, Orthodoxy and Islam in Russia 9881725, w: Religion und Integration im Moskauer Russland. Konzepte und Praktiken, Potentiale und Grenzen 14.-17. Jahrhundert, hrsg. von L. Steindorff, Forschungen zur osteuropäischen Geschichte 76, Wiesbaden 2010, 125. 
szereg ważnych ośrodków (m.in. Damaszek i Jerozolima) przeszło pod panowanie wyznawców islamu ${ }^{14}$.

Omówiony wyżej fragment kodeksu zdobią, rzecz jasna, miniatury. $\mathrm{Na}$ dwóch spośród nich, umiejscowionych na początku i na końcu sekwencji W Бохмите ерєтиц ' (fol. 677 i 682), został najprawdopodobniej ukazany Mahomet. Jednoznaczną identyfikację obu wizerunków utrudnia jednak fakt, iż nie zaopatrzono ich, podobnie jak wielu innych podobizn postaci historycznych, pojawiających się na kartach zwodu, w podpisy. Należy również podkreślić, iż kwestia ewentualnych przedstawien ikonograficznych założyciela islamu w rękopisie РНБ, F.IV.151 nie została do tej pory podniesiona w literaturze przedmiotu. Badacze rosyjscy w swoich dotychczasowych studiach koncentrowali się bowiem głównie na tych częściach kompilacji, które poświęcone są historii Rusi ${ }^{15}$.

Zanim przystappimy do analizy dwóch wspomnianych wyżej miniatur, warto jeszcze zwrócić uwagę na jedną interesującą kwestię: strony, na których znajduje się właściwy tekst $W$ Бохмитє єрєтиц' $\mathbf{B}$, nie zostały w ogóle opatrzone iluminacjami (677'-681'). Fenomenu tego nie należy jednak wiązać z próbą przeszczepienia na grunt kultury staroruskiej, charakterystycznych dla świata islamu, ograniczeń i zakazów sporządzania przedstawień figuratywnych, w szczególności zaś tworzenia wizerunków Mahometa. Jak wykazali znawcy zagadnienia, twórcy omawianej tu kompilacji konsekwentnie nie zdobili ilustracjami zamkniętych sekwencji monotematycznych, np. pierwotnie samodzielnych utworów literackich, wplecionych w treść zwodu ${ }^{16}$.

W jakim kontekście pojawia się w rękopisie РНБ, F.IV.151 opowieść o Mahomecie i narodzinach islamu? Na karcie 676', poprzedzającej stronę z kilkoma pierwszymi wersami interesującego nas tu tekstu, odnajdujemy adnotację, iż po śmierci cesarza bizantyńskiego Herakleonasa (641) rządy objął Konstans [II] (641-668), syn Konstantyna [III] i panował przez następne 27 lat. Powyżej zapisu umiejscowiono miniaturę. W jej lewym górnym rogu ukazano zmarłego Herakleonasa, spoczywającego w grobie, zaś w centrum kompozycji tronującego Konstansa $\mathrm{II}^{17}$. Na kluczowej z punktu widzenia naszych rozważań karcie 677 czytamy natomiast o tym, że za rządów Konstansa II miała miejsce klęska żywiołowa: zerwał się nadzwyczaj silny wicher, który

${ }^{14}$ Por. Лицевой летописный свод ХVI в., s. 399-412; Летописеи Еллинский и Римский, s. 405-409. Zob. Творогов, О составе, s. 356.

15 Por. Арциховский, Древнерусские миниатюры, s. 41-154; Подобедова, Миниатюры, s. 102-332; Черный, Некоторые особенности, s. 69. Wyjątkowe w tym kontekście wydają się badania Aleksandra A. Amosova (Лицевой летописный свод, s. 223-303), koncentrujące się na pierwszych dwóch tomach kompilacji (ГИМ, Музейск. собр. 358 oraz БАН, 17.17.9), zawierających wykład historii powszechnej od stworzenia świata do lat siedemdziesiątych I w. n.e. Interesujący nas w niniejszym studium rękopis РНБ, F.IV.151 jest więc chyba najsłabiej, jak dotąd, przebadaną częścią Iluminowanego zwodu latopisarskiego.

${ }^{16}$ Por. Амосов, Лицевой летописный свод, s. 235-237.

${ }^{17}$ Por. Лицевой летописный свод XVI в., s. 388. 
wyrywał drzewa z korzeniami i poprzewracał słupy syryjskim anachoretom. Katastrofa ta, zgodnie z poetyką bizantyńskiej historiografii, miała zwiastować nadejście innego kataklizmu - w jakiś czas później objawił się fałszywy prorok, przywódca Saracenów: Bohmit ${ }^{18}$.

Warto tu zwrócić uwagę na kwestię chronologii. Autorzy staroruscy nie zawsze poprawnie datują nauczanie Mahometa i początek podbojów arabskich, de facto mających miejsce za panowania cesarza Herakliusza (610-641). Niejednokrotnie lokują te wydarzenia w okresie krótkich rządów Konstantyna III i Herakleonasa (641 r.), a czasami nawet wiążą je z epoką Konstansa II (641668 ), przesuwając tym samym narodziny islamu o kilka dekad. Błąd ten pojawia się w Iluminowanym zwodzie latopisarskim, w ślad za stanowiącym jego osnowę Latopisem helleńskim i rzymskim drugiej redakcji ${ }^{19}$. Odnajdujemy go także na kartach jednego z podstawowych źródeł informacji z zakresu historii powszechnej, którym rozporządzali staroruscy historiografowie: w przekazie kroniki Jerzego Mnicha, zarówno w jej tłumaczeniu na język staro-cerkiewno-słowiański ${ }^{20}$, jak i w greckim oryginale ${ }^{21}$. Charakterystyczne dla analizowanej tu kompilacji zaburzenie chronologii jest zatem konsekwencją omyłki, do której doszło już na gruncie bizantyńskim w IX w.

Powróćmy jednak do miniatury na karcie 677 . W jej górnej części wyobrażono cesarza Konstansa II, zasiadającego na tronie w otoczeniu dworzan, a także personifikację wiatru (wychylającą się zza chmury postać chłopca, dmącego $\mathrm{w}$ trąbę). W niższych rejestrach przedstawienia widzimy gnące się w podmuchach wichru drzewa, poprzewracane kolumny oraz kilku słupników, zrozpaczonych utratą narzędzi swej ascezy. Na lewo od ich sylwetek dostrzegamy wyłaniającą się zza skał grupę mężczyzn, której przewodzi człowiek ubrany w ciemnozielone szaty, w prawej dłoni dzierżący zwój pergaminu. Jego włosy, broda i wąsy mają kolor brązowy.

Przyjmując, że na omawianej miniaturze - zgodnie z założeniami artystycznymi kompilacji - zostały przedstawione wszystkie osoby wspomniane w teście zamieszczonym na tej samej stronie, można stwierdzić, iż mężczyzną w zielonym płaszczu jest Mahomet, ukazany w gronie swoich uczniów. Warto też zauważyć, iż jego wizerunek został umiejscowiony w lewej części kompozycji. W literaturze przedmiotu spotkać można sądy, iż rozmieszczenie obiektów na miniaturach $\mathrm{w}$ analizowanym zabytku odzwierciedlało niekiedy ich położenie w rzeczywistej przestrzeni: lewa strona oznaczała wschód, a prawa - zachód (w konsekwencji kierunek południowy wyznaczała górna

\footnotetext{
${ }^{18}$ Por. Лицевой летописный свод XVI в., s. 389.

${ }^{19}$ Por. Летописеи Еллинский и Римский, s. 401-402.

${ }^{20}$ Por. Книгы временыя и образныя Георгия Мниха. Хроника Георгия Амартола в древнем славянорусском переводе. Текст, исследование и словарь, ред. В.М. Истрин, t. 1, Петроград $1920,449$.

${ }^{21}$ Por. Georgius Monachus, Chronicon, ed. C. de Boor, t. 2, Leipzig 1904, 697, 9-15.
} 
krawędź kompozycji, a północny - dolna ${ }^{22}$. Staroruski artysta, przedstawiając muzułmańskiego proroka na lewo od grupy anachoretów, chciał być może podkreślić, iż wywodził się on z obszaru, położonego na wschód od bizantyńskiej Syrii.

Druga z interesujących nas tu miniatur znajduje się na fol. 682. W towarzyszącym jej tekście czytamy o tym, iż po śmierci Mahometa na południu ukazała się gwiazda w kształcie kopii (kometa?), zwiastująca kolejne, brzemienne w skutkach dla cesarstwa, wydarzenie. Jak stwierdza, w ślad za wcześniejszą bizantyńsko-ruską tradycją historiograficzną, autor zwodu, „Arabowie dawniej zwani Saracenami (аравитани си Арєвлє Гдеєеїи срдчинанї̈)" porzucili Arabię (Аравїю шстдвившє) ${ }^{23}$, zaatakowali Bizancjum i zaczęli sukcesywnie zajmować kolejne tereny, znajdujące się we wschodniej części imperium, szybko dochodząc do wybrzeża [Morza Śódziemnego] ${ }^{24}$. Twórca wzmiankowanej miniatury oddał wiernie treść przekazu, wyobrażając tuż przy górnej krawędzi kompozycji (odpowiadającej, jak pamiętamy, stronie południowej) kometę. Tuż pod nią, w lewym górnym rogu odnajdujemy wizerunek zmarłego Mahometa, spoczywającego w grobie. W centrum widzimy zaś jazdę arabska, wyruszającą na podbój cesarstwa, którego posiadłości zostały ukazane dość emblematycznie: pod postacią dwóch grup kamiennych budowli, otoczonych pokaźnych rozmiarów murami obronnymi. Godny odnotowania jest również kierunek, w którym przemieszczają się zbrojni: sylwetki koni i jeźdźców zwrócone są w prawą stronę, co odpowiadałoby rzeczywistemu przebiegowi ekspansji: ze wschodu na zachód.

Przyjrzyjmy się teraz uważniej obu domniemanym przedstawieniom ikonograficznym muzułmańskiego proroka. Zestawiając ze sobą wyobrażenia z fol. 677 i 682 dostrzec można przede wszystkim uderzającą zbieżność fizjonomii obu postaci. Nie ulega wątpliwości, iż na obu miniaturach ukazano tego samego mężczyznę. Jego ,portrety” pozbawione jednak zostały jakichkolwiek

${ }^{22}$ Por. Черный, Некоторые особенности, s. 70-73; Ульянов, Изучение, s. 108-119.

${ }^{23}$ Por. Лицевой летописный свод XVI в., s. 399-400. Co ciekawe, analizowany tu tekst jest jednym z nielicznych utworów z bizantyńsko-słowiańskiego kręgu cywilizacyjnego, na kartach którego pobratymcy Mahometa zostali określeni wprost przynależnym im etnonimem. W zdecydowanej większości przekazów, zamiast terminów Arabowie i Arabia, pojawiają się takie rzeczowniki jak Saraceni, Izmailici czy (H)agareni, odwołujące się do wschodniochrześcijańskich wyobrażeń na temat pochodzenia tego ludu. Por. L.S. Chekin, The Godless Ishmaelites: The Image of the Steppe in Eleventh to Thirteenth Century Rus', „Russian History” 19 (1992) nr 1, 9-28; М.А. Батунский, Россия и ислам, t. 1, Москва 2003, 35-36; Н.И. Зубов, Заметки по поводу этнонима сарацины в некоторых древнерусских памятниках, w: Етнолингвистичка проучавања српског и других славенских језика. У част академика Светлане Толстој: зборник радова, уред. П. Пипер - Љ. Раденковић, Београд 2008, 163-171; T. Wolińska, Arabowie, Agareni, Izmailici, Saraceni. Kilka uwag na temat nazewnictwa, w: Bizancjum i Arabowie. Spotkanie cywilizacji. VI-VIII w., red. T. Wolińska - P. Filipczak, Warszawa 2015, 31-46; taż, Arabs, (H)agarenes, Ishmaelites, Saracens - a Few Remarks about Naming, w: Byzantium and the Arabs: the Encounter of Civilizations from Sixth to Mid-Eighth Century, ed. T. Wolińska - P. Filipczak, Byzantina Lodziensia 22, Łódź 2015, 22-37.

${ }^{24}$ Por. Лицевой летописный свод XVI в., s. 400-414. 
cech indywidualnych. Jak podkreślają znawcy zagadnienia, stereotypizacja wizerunku jest zjawiskiem charakterystycznym dla znakomitej większości ilustracji, zdobiących wszystkie tomy Iluminowanego zwodu latopisarskiego. Warstwa wizualna została świadomie opracowana w ten sposób, by czytelnik już na pierwszy rzut oka mógł rozpoznać, do jakiej grupy społecznej zalicza się każda z wyobrażonych na miniaturach osób (władca, wojownik, duchowny, prorok, itp.). Co więcej, przedstawienia postaci ludzkich cechuje tu też brak zróżnicowania etnicznego i chronologicznego w obrębie przyjętych klisz myślowych. Dla przykładu: cesarz bizantyński z VI w. powinien, zgodnie z założeniami twórców zwodu, wyglądać dokładnie tak samo jak car bułgarski z X w., król serbski z XIII w. czy książę moskiewski z XVI stulecia, gdyż wszyscy ci władcy są prawosławnymi monarchami ${ }^{25}$.

$\mathrm{W}$ analizowanych tu wizerunkach Mahometa uderza również brak jakichkolwiek prób orientalizacji stroju. Zastanawia, że twórcy miniatur nie odwołali się w trakcie pracy nad nimi chociażby do kanonu przedstawiania św. Jana z Damaszku (ok. 675 - ok. 750), żyjącego nieomal w tym samym czasie co muzułmański prorok i na pokrewnym kulturowo obszarze. Tradycja ukazywania tego świętego, zawierająca w sobie pewne elementy wschodnie, musiała być autorom rękopisu РНБ, F.IV.151 znana. Dość wskazać, że w manuskrypcie tym, na fol. 772' odnajdujemy wyobrażenie Damasceńczyka, wykonane w sposób całkowicie zgodny z kanonem, rozpowszechnionym w ikonografii Kościoła wschodniego: w brunatno-brązowych szatach i w charakterystycznym, białym zawoju na głowie ${ }^{26}$.

Warto również pochylić się przez chwilę nad kwestią kolorystyki. Jak wspomniano wyżej, wierzchnie okrycie Mahometa ma barwę ciemnozieloną. W fakcie tym nie należy, oczywiście, doszukiwać się kolejnego nawiązania do ikonografii muzułmańskiej, w której odcień ten zajmuje niezwykle ważne miejsce. Można jednak przypuszczać, iż zieleń nie została na obu interesujących nas tu wizerunkach zastosowana przypadkowo. Aleksander A. Amosov, poddawszy gruntownej analizie miniatury zdobiące dwa inne tomy Iluminowanego zwodu latopisarskiego (ГИМ, Музейск. собр. 358 oraz БАН, 17.17.9), doszedł do wniosku, iż ich twórcy dość konsekwentnie stosowali swoisty klucz kolorystyczny w sporządzaniu wizerunków poszczególnych postaci historycznych. W szatach o barwie błękitnej ukazywali osoby kojarzące się ze sferą sacrum, zaś w czerwonym odzieniu (przez konotacje z cesarską purpura) - monarchów. Kolor zielony zarezerwowany był zaś dla „aktorów drugiego

${ }^{25}$ Por. Амосов, Лицевой летописный свод, s. 227; Морозов, Лицевой свод, s. 207-215.

${ }^{26}$ Рог. Лицевой летописный свод ХVI в. Всемирная история, ред. Х.Х. Мустафин, t. 9, Москва 2014, 80. Na wschodni zawój, jako charakterystyczny element kanonu wyobrażania św. Jana z Damaszku, zwracali też uwagę twórcy bizantyńskich hermenei. Zob. Dionizjusz z Furny, Hermeneia czyli objaśnienie sztuki malarskiej, tłum. I. Kania, red. M. Smorag Różycka, Kraków 2003, 212. Por. A. Tradigo, Ikony i święci prawosławni, tłum. E. Maciszewska, Warszawa 2011, 319. 
planu" - mniej ważnych z perspektywy narracji postaci, władców mniejszych państw, a nawet niektórych pogańskich cesarzy starożytnego Rzymu ${ }^{27}$.

Do jakich wzorców ikonograficznych odwołali się ruscy iluminatorzy, sporządzając wyobrażenia Mahometa? Odpowiedzi dostarczyć może porównanie wizerunków założyciela islamu z przedstawieniami herezjarchów, zamieszczonymi w rękopisie РНБ, F.IV.151. Niestety, nie odnajdziemy w nim najprawdopodobniej ani jednego portretu Maniego (216-274). Twórcy ruchów heterodoksyjnych w obrębie chrześcijaństwa z III-IV w. pojawiają się natomiast na kartach analizowanego manuskryptu wielokrotnie. Ariusz (250/256336) ukazany został na fol. 129-139 (na których zamieszczono tekst $W$ Apïn єрєтиц'в - O Ariuszu heretyku) i 174'-175, jako sędziwy mężczyzna z długą białą brodą, odziany w strój kapłana w kolorze brunatno-brązowym lub fioletowo-błękitnym ${ }^{28}$. Jedynym elementem, który odróżnia sylwetkę aleksandryjskiego prezbitera i jego zwolenników od postaci „ortodoksyjnych” duchownych, stojących po stronie uchwał soboru ekumenicznego w Nicei, jest brak nimbu. W analogiczny sposób wyobrażony został Nestoriusz (384-451). Na kartach 347'-350' i 379-379' (obok tekstu W Nєсторїи єрєтиц ' - O Nestoriuszu heretyku) odnajdujemy kilka miniatur, na których występuje on nieodmiennie w szatach biskupich, bez nimbu ${ }^{29}$.

Interesujące z punktu widzenia naszych rozważań wyobrażenie znajduje się też na fol. 696'. Umieszczono tu miniaturę, ilustrującą tekst o rozprzestrzenianiu się jednej z herezji dualistycznych, tj. o przypadającej na czas rządów Konstantyna IV (668-685) działalności Konstantyna-Sylwiana, nawiązującego w swych twierdzeniach do nauk Pawła z Samosaty (ok. 200 - ok. 275) i jego brata Jana, synów manichejki o imieniu Kalinika. Na wspomnianym artefakcie odnajdujemy zarówno wizerunek matki obu herezjarchów (odzianej w czerwony maforion), jak i ich samych. Paweł, Jan i wszyscy kontynuatorzy ich myśli (wśród których znajduje się, być może, wspomniany Konstantyn-Sylwian) zostali przedstawieni w taki sam sposób jak Mahomet: jako brodaci mężczyźni w średnim wieku, w szatach osób świeckich, bez nimbów ${ }^{30}$.

Reasumując, muzułmański prorok został ukazany na miniaturach w rękopisie РНБ, F.IV.151 w nieomal identyczny sposób jak herezjarchowie, których twierdzenia, wyrastające $\mathrm{z}$ myśli chrześcijańskiej, zostały potępione przez

${ }^{27}$ Рог. Амосов, Лицевой летописный свод, s. 274-287 і 292.

${ }^{28}$ Рог. Лицевой летописный свод ХVI в. Всемирная история, ред. Х.Х. Мустафин, t. 6, Москва 2014, 269-289 і 360-361. Kanon przedstawiania Ariusza w scenie pierwszego soboru ekumenicznego w Nicei w roku 325: Dionizjusz z Furny, Hermeneia czyli objaśnienie sztuki malarskiej, s. 216: „Stojący Ariusz także nosi szaty biskupie”.

${ }^{29}$ Por. Лицевой летописный свод ХVI в. Всемирная история, ред. Х.Х. Мустафин, t. 7, Москва 2014, 200-206 і 263-264. Wzorzec wyobrażania Nestoriusza w scenie trzeciego soboru ekumenicznego w Efezie w roku 431: Dionizjusz z Furny, Hermeneia czyli objaśnienie sztuki malarskiej, s. 217: „Naprzeciwko nich Nestoriusz, starzec w szatach arcybiskupich, rozmawiający z nimi”.

${ }^{30}$ Por. Лицевой летописный свод XVI в., t. 8, s. 428. 
Kościół. Czytelnym nawiązaniem do kanonu wyobrażania proroków jest natomiast zwój pergaminu, dzierżony przez założyciela islamu w prawej dłoni na jednej z miniatur (fol. 677) ${ }^{31}$. Wizerunki te korespondują z wymową ideową tekstu $W$ Бохмите єрєтиц się też doskonale w charakterystyczną dla literatury staroruskiej tendencję do postrzegania Mahometa jako fałszywego proroka, zaś stworzonej przez niego religii - jako jednej z wielu herezji w łonie chrześcijaństwa.

\section{Mahomet na kartach rękopisu PHБ, F.IV.151 - aspekty literackie.} Jak wspominałam wyżej, rozdział $W$ Бохмитє єрєтиц' $\mathbf{B}$ nie jest utworem oryginalnym, lecz tekstem, który za pośrednictwem Latopisu helleńskiego i rzymskiego drugiej redakcji został zaczerpnięty ze staro-cerkiewno-słowiańskiego przekładu kroniki Jerzego Mnicha. Co ciekawe, Hamartolos, snując swą opowieść o działalności Mahometa i narodzinach islamu, również posiłkował się źródłami wcześniejszymi. Dość stwierdzić, iż wkomponował on w obręb swojego tekstu fragment traktatu polemicznego autorstwa Michała Synkellosa (ok. 760-846). Dzieło to nie przetrwało do naszych dni w formie całościowej ${ }^{33}$. Oprócz obszernej sekwencji przytoczonej przez Jerzego Mnicha i dzięki temu zachowanej w greckich i słowiańskich odpisach jego kroniki oraz w staroruskich utworach historiograficznych, bazujących na dziele Hamartolosa, znane są nam tylko te fragmenty Synkellosowej polemiki z islamem, które zostały włączone w treść trzeciej redakcji Nomokanonu 14. Rozdziałów, powstałej na zlecenie patriarchy konstantynopolitańskiego Tarazjusza (784-806) i przetłumaczonej na język staro-cerkiewno-słowiański najprawdopodobniej już w X w. Najstarszym istniejącym odpisem tego przekładu jest tzw. Kormcza Efrema, rękopis staroruski, datowany na początek XII w. (ГИМ, Син. 227) ${ }^{34}$.

${ }^{31}$ Por. C. Walter, Sztuka i obrzqdek Kościoła bizantyńskiego, tłum. K. Malcharek, Warszawa 1992, 224-225.

${ }^{32}$ Warto tu też zwrócić uwagę na podobieństwo tytułów rozdziałów poświęconych Ariuszowi, Nestoriuszowi i Mahometowi: W Арїи єрєтиц' $\mathrm{B}-\mathrm{O}$ Ariuszu heretyku; W Nєсторїи єрєтиц' $-\mathrm{O}$ Nestoriuszu heretyku; $W$ Бохмитє єрєтиц $\mathrm{B}-$ O Bohmicie heretyku.

33 Por. В.Г. Васильевский - П.В. Никитин, Сказания о 42 Аморийских мучениках и иерковная служба им, Mémoires de l'Académie Impériale des Sciences de St.-Pétersbourg, VIII ${ }^{\mathrm{e}}$ serie: Classe historico-philologique VII/2, St.-Pétersbourg 1905, 111-113; H. Hunger, Die hochsprachliche profane Literatur der Byzantiner, Bd. 1: Philosophie, Rhetorik, Epistolographie, Geschichtsschreibung, Geographie, München 1978, 261; Christian-Muslim Relations. A Bibliographical History, ed. D. Thomas - B. Roggema, vol. 1: 600-900, History of Christian-Muslim Relations 11, Leiden - Boston 2009, 632, 731. Co ciekawe, w jednym z greckich odpisów kroniki Jerzego Mnicha, znajdującym się obecnie w zbiorach Biblioteki Narodowej Francji (MS BNF Coislin 305, fol. 312'), odnajdujemy wzmiankę, iż w tekst o Mahomecie został wpleciony wcześniejszy utwór autorstwa Michała Synkellosa.

${ }^{34}$ Por. Я.Н. Щапов, Номоканон Иоанна Схоластика и Синтагма 14 титулов у Славян в IX-X в8., w: Beiträge zur byzantinischen Geschichte im 9.-11. Jahrhundert, hrsg. von V. Vavřinek, Praga 1978, 387-411; К.А. Максимович, Древнерусская Ефремовская кормчая XII в.: локализация перевода в связи с историей текста, w: Лингвистическое источниковедение 
Jaki obraz Mahometa wyłania się z utworu W Бохмитє єрєтиц'b, w wersji przekazanej przez autorów Iluminowanego zwodu latopisarskiego? Przede wszystkim w rękopisie РНБ, F.IV.151 czytamy o tym, że nasz bohater był przywódcą Saracenów (срдчиньскы ндчалмикъ) oraz złym i fałszywym prorokiem (злыи пр९къ Бохмитъ и лживыи) ${ }^{35}$. W dość plastyczny sposób kreślą też twórcy kompilacji, w nawiązaniu do tradycji narracyjnej, ukształtowanej w historiografii bizantyńskiej, obraz prapoczątków islamu. $Z$ ich tekstu dowiadujemy się zatem, że Mahomet w młodości, podczas licznych podróży do Palestyny, które odbywał wiodąc karawany swej ówczesnej chlebodawczyni i jedynej małżonki Chadidży, stykał się z żydami i chrześcijanami, z których pism przejmował niektóre nauki. U jego boku miał się też wówczas pojawić pewien nieznany z imienia arianin, podający się za mnicha (być może, tożsamy z Sergiuszem Bahira, postacią znaną z przekazów arabskich, syryjskich i bizantyńskich) ${ }^{36}$. Pod wpływem bezpośrednich kontaktów z nim oraz innymi przedstawicielami dwóch religii monoteistycznych (judaizmu i chrześcijaństwa), Mahomet miał stworzyć, jak stwierdzają expressis verbis nasi autorzy, własną herezję (прєлєсть єрєтичєствд єго) ${ }^{37}$.

O kolejne interesujące elementy wzbogaca wizję narodzin islamu, wyłaniającą się z analizowanego źródła, przekaz tej partii tekstu, która została zapożyczona z traktatu Michała Synkellosa. Według tego autora, Mahomet miał w zwyczaju rozmawiać z przedstawicielami wielu różnych religii, herezji i wyznań, od każdego z interlokutorów przejmując jakiś inny element. W rękopisie РНБ, F.IV.151 czytamy zatem o tym, iż wchodził on często w dyskusje z żydami i zwolennikami nieortodoksyjnego chrześcijaństwa, tj. arianami i nestorianami (съ Хр'тьаны рєкшє Къ арї̈но" и к несторїаномъ). Od wyznawców judaizmu przejął w efekcie tych dysput ideę monoteizmu, od arian - pojęcie stworzonego Słowa i Ducha, zaś od nestorian - чর̈вкослужєнїє (antropolatrię). Zebrawszy wszystkie te elementy, stworzył na ich podstawie własną wiarę (в вpor) ${ }^{38}$. Warto tu też zauważyć, iż w świetle niniejszego passusu - pojawiającego się

и история русского языка (2004-2005), Москва 2006, 102-113; tenże, Byzantine Law in Old Slavonic Translations and the Nomocanon of Methodius, „Byzantinoslavica” 65 (2007) 9-18.

${ }^{35}$ Por. Лицевой летописный свод ХVI в., t. 8, s. 389.

${ }^{36}$ Por. S. Gerö, The Legend of the Monk Bahīrā, the Cult of the Cross and Iconoclasm, w: La Syrie de Byzance à l'Islam: VII -VIII siècles, Actes du Colloque international „De Byzance à l'Islam", Lyon - Maison de l'Orient Méditerranéen, Paris - Institut du Monde Arabe, 11-15 Septembre 1990, publ. par P. Canivet - J.-P. Rey-Coquais, Publications de l'Institut Français de Damas 137, Damas 1992, 47-57; B. Roggema, The Legend of Sergius Bahīrā. Eastern Christians Apologies and Apokalyptic in Response to Islam, Leiden - Boston 2009; A. Bahkou, The Monk Encounters the Prophet. The Story of the Encounter between Monk Bahira and Muhammad as it is Recorded in the Syriac Manuscript of Mardain 259/2, „Cultural and Religious Studies” 3 (2015) nr 6, 349-357; tenże, The Story of the Encounter between Monk Bahira and Muhammad as it is Recorded in the Syriac Manuscript of Mardain 259/2: ,, The Monk Encounters the Prophet”, Lewiston 2017.

${ }^{37}$ Por. Лицевой летописный свод XVI в., t. 8, s. 391.

${ }^{38}$ Por. tamże. 
w nieomal identycznym brzmieniu w Latopisie helleńskim i rzymskim drugiej redakcji, w słowiańskim przekładzie kroniki Jerzego Mnicha oraz w tekście Michała Synkellosa, zachowanym w staroruskich odpisach Nomokanonu 14. Rozdziałów (m.in. w Kormczej Efrema) - ortodoksyjni chrześcijanie, uznający postanowienia pierwszych soborów ekumenicznych, zostali wyraźnie wyłączeni z kręgu potencjalnych inspiratorów Mahometa ${ }^{39}$.

Co ciekawe, w innych utworach staroruskich katalog religii, wyznań i herezji, z przedstawicielami których miał się stykać późniejszy założyciel isla$\mathrm{mu}$, ulega dalszemu rozszerzeniu, np. we wspomnianym już wyżej Latopisie Nikonowskim (połowa XVI w.) oraz w zależnej od niego tekstologicznie zachodnioruskiej redakcji Ruskiego Chronografu (XVI w.) czytamy o tym, iż rozmawiał on z żydami, chrześcijanami (ortodoksyjnymi?), arianami, nestorianami, manichejczykami, jakobitami (syryjskimi monofizytami), Armeńczykami (nieuznającymi postanowień soboru w Chalcedonie), христораздорникы (autor tekstu ma tu zapewne na myśli chrystolitów, tj. „rozszczepiających Chrystusa"), donatystami oraz lampetianami ${ }^{40}$. Można przypuszczać, iż nazwy trzech ostatnich odłamów zostały przez twórców Latopisu Nikonowskiego zapożyczone z traktatu $O$ herezjach Jana Damasceńskiego. Pozwala tak twierdzić fakt, iż we wspomnianym utworze poglądy chrystolitów, donatystów i lampetian zostały omówione w tej samej partii narracji (jako herezje 93, 95 i 98$)^{41}$.

Tekst herezjologiczny Jana z Damaszku ukształtował też w znacznym stopniu obraz islamu w literaturze staroruskiej i był jednym z najważniejszych źródeł, rozpowszechnionego na interesującym nas tu gruncie, wyobrażenia o stworzonej przez Mahometa religii jako o jednej z herezji w łonie chrześcijaństwa. Traktat ten - w tradycji bizantyńsko-słowiańskiej błędnie identyfikowany jako Panarion Epifaniusza z Salaminy (310/320 - 402/403), którego skrót de facto stanowi - został najprawdopodobniej przetłumaczony na język staro-cerkiewno-słowiański na początku X w. w Bułgarii, w obrębie Nomokanonu 14. Rozdziałów. Przekład ten musiał trafić na Ruś najpóźniej w pierwszych dekadach XII w., w których powstawała zawierająca go Kormcza Efre$m a$ (ГИМ, Син. 227) ${ }^{42}$. Co ciekawe, w rękopisie tym nie odnajdziemy jednak

${ }^{39}$ Por. Летописеи Еллинский и Римский, s. 402; Книгы временыя и образныя Георгия Мнuха, s. 450; Syntagma XIV titulorum sine scholiis secundum versionem Palaeo-Slovenicam, adjecto textu Graeco e vetustissimis codicibus manuscriptis exarato, ed. V.N Beneševič, t. 1, Petropoli 1906, 701.

${ }^{40}$ Por. Летописный сборник, именуемый Патриаршею или Никоновскою летописью, Полное собрание русских летописей 9, Москва 2000, 59; Русский хронограф. Хронограф Западнорусской редакичи, Полное собрание русских летописей 22/2, Петроград 1914, 123. Zob. Клосс, Никоновский свод, s. 171.

${ }^{41}$ Por. Johannes Damascenus, Liber de haeresibus (93) 1-3, (95) 1-4, (98) 1-9, , ed. B. Kotter, w: Die Schriften des Johannes von Damaskos, t. 4, PTS 22, Berlin - New York 1981, 57-59, thum. A. Zhyrkova: Jan Damasceński, O herezjach, ŹMT 59, Kraków 2011, 133-134.

${ }^{42}$ Por. H. Miklas, Zur kirchenslavischen Überlieferung der Häresiengeschichte des Johannes 
ostatniego rozdziału traktatu $O$ herezjach, poświęconego islamowi. W trzeciej redakcji Nomokanonu 14. Rozdziatów, na której bazuje Kormcza Efrema, zamiast polemiki Jana Damasceńskiego z mahometanizmem zamieszczono bowiem z jakiś względów skrót antymuzułmańskiego tekstu Michała Synkello$\mathrm{sa}^{43}$. Słowiańskie tłumaczenie rozdziału o islamie autorstwa Damasceńczyka powstało więc najprawdopodobniej dopiero po 1219 r. w Serbii, na potrzeby nowej kompilacji prawnej, tj. Nomokanonu św. Sawy. Na Rusi stało się ono znane ok. 1270 roku $^{44}$.

Wyobrażenie o Mahomecie jako herezjarsze/fałszywym proroku charakterystyczne jest więc głównie dla tych zabytków piśmiennictwa staroruskiego, które są treściowo zależne od wspomnianych wyżej utworów bizantyńskich: traktatów Jana Damasceńskiego i Michała Synkellosa oraz kroniki Jerzego Mnicha, zawierającej czytelne zapożyczenia z tekstu tego ostatniego autora. Oprócz wspomnianych wyżej utworów historiograficznych, prezentujących wykład dziejów powszechnych (Latopisu helleńskiego i rzymskiego, Latopisu Nikonowskiego oraz obu redakcji Chronografu Ruskiego z 1512 r.), warto tu wskazać m.in. skompilowany w latach 40. XV w. Rogożski Chronograf (РГБ, f. 247.253: No и срацинскыи хжівыи пророкъ и начданикъ Бохмитъ) ${ }^{45}$, Latopis Zmartwychwstania, datowany na lata 1542-1544 (С рациньскіє в Ђры лживаго пророка) $)^{46}$ oraz XVI-wieczny Latopis Nikotaja A. Lwowa (При семz высть Бохмитъ еретикъ, С рацинскій ндчдльникъ, змый и лживый $)^{47}$.

Przeświadczenie o tym, iż islam nie jest niczym więcej jak tylko jedną $\mathrm{z}$ herezji w łonie chrześcijaństwa, towarzyszyło także wielu autorom staroruskim, opisującym bieżące wypadki. Na ślad tego rodzaju wyobrażeń

von Damaskus, „Monumenta Linguae Slavicae” 15 (1981) 331-333; W.K. Hanak, The Impact of Byzantine Imperial Thought upon Vladimirian-Jaroslavian Russia, „Byzantine Studies/Études Byzantines" 8-12 (1981-1985) 125; Максимович, Древнерусская Ефремовская кормчая, s. 102-113; tenże, Byzantine Law, s. 11; Bushkovitch, Orthodoxy, s. 125-126; Średniowieczne herezje dualistyczne na Bałkanach. Źródła słowiańskie, red. G. Minczew - M. Skowronek - J.M. Wolski, Series Ceranea 1, Łódź 2015, 237; А.А. Лушников, Панарион Епифания Кипрского и восприятие язычества в историософских взглядах древнерусских книжников XI-XIV вв., „Вестник Самарского университета. История, педагогика, филология" 7 (2015) 95-100.

${ }^{43}$ Por. Syntagma XIV titulorum, s. 701-704.

${ }^{44}$ Por. Zakonopravilo or the Nomocanon of Saint Sava. The Ilovica Manuscript from 1262. Photoprint reproduction, ed. and appendices written by M.M. Petrović, Beograd 1991, fol. 369'-373'; Я.Н. Щапов, Византийское и южснославянское правовое наследие на Руси в XI-XIII в., Москва 1978, 119 i 261-270; Miklas, Zur kirchenslavischen, s. 338-343; M.M. Petrović, Saint Sava's Zakonopravilo on the Teachings of Muhammed, Belgrade 1997, 7; Maksimovich, Byzantine Law, s. 11; S. Prodić, Knjiga 'O jeresima' prepodobnog Jovana Damaskina kao 61. poglavlje sarajevskog rukopisa 'Zakonopravila'svetog Save Srpskog, Šibenik 2016, 9-14.

${ }^{45}$ Рогожский хронограф: текст, ред. Т.В. Анисимова, w: Летописи и хроники. Новые исследования. 2009-2010, ред. О.Л. Новикова, Москва - Санкт-Петербург 2010, 67.

46 Летопись по Воскресенскому списку, Полное собрание русских летописей 7, СанктПетербург 1856, 249.

47 Львовская летопись, Полное собрание русских летописей 20/1, Санкт-Петербург 1910, 33. 
natrafiamy m.in. w opowieści - pojawiającej się na kartach kilku utworów historiograficznych, np. Latopisu Sofijskiego pierwszego (XV w.), Latopisu Symeonowskiego (koniec XV w.), zwodu moskiewskiego z końca XV stulecia, Latopisu wołogodzko-permskiego z przełomu XV i XVI w. oraz Latopisu Nikanora z 2. poł. XV w. - o osobistej konwersji na islam, dokonanej przez pewnego mieszkańca Jarosławia o imieniu Zosym w 6770/1262 r. Relacjonując to wydarzenie, nasi kronikarze stwierdzają wprost, że stał się on $b i$ surmaninem (muzułmaninem), zwiedziony przez kłamstwa fałszywego proroka Mahometa (И высть весерменинъ, въступивъ въ прелесть лжаго пророка Maхмєта $)^{48}$. Interesującym świadectwem jest również pouczenie metropolity Focjusza (1408-1431), skierowane do mieszkańców Pskowa w 1422/1425 r., zawierające konstatację, iż heretyków i muzułmanów należy traktować w ten sam sposób, tzn. karać anatemą (в том Бєзъзаконнии Будущих, якожє уБє оканнаго Магмета ересовуауццих, отаучайте и тех Божих церкви ${ }^{49}$. W podobnym tonie wyraża się też o islamie książę moskiewski Wasyl II (1425-1462) w liście do cesarza bizantyńskiego Jana VIII Paleologa (1425-1448), przytoczonym w Latopisie Nikołaja A. Lwowa pod datą roczną 6946/1438 (оканнаго жє и Богомерскаго Mодмеөд и злочестивую ерєсь) ${ }^{50}$. Mianem fałszywego proroka określają Mahometa także twórcy Latopisu Kazańskiego, zawierającego relację ze zdobycia Kazania przez wojska Iwana IV Groźnego w 1552 r. (А вашъ Аживы пророкъ Махметв не поможетъ вамъ ничемъ же, ныне же въ него в Вруєте зА' ПреАстившеся и не по знавъше истинного Бога $)^{51}$ oraz książę Andrzej Kurbski (1528-1583) w jednym ze swoich tekstów polemicznych $\left(\mathfrak{E}_{\Gamma, \lambda}\right.$ үжє умножишася Антихристовы стаинники на земли Срацынє, псєвА.профита MагметА чествчющєе) $)^{52}$.

W tym miejscu należy wyraźnie podkreślić, iż ukazywanie założyciela islamu jako fałszywego proroka, a islamu jako herezji, nie było jedynym sposobem prezentowania interesującego nas tu zagadnienia w literaturze staroruskiej. Ponieważ kwestia ta wykracza poza ramy tematyczne niniejszego

${ }^{48}$ Софийская первая летопись, Полное собрание русских летописей 5, Санкт-Петербург 1851, 190; Софийская первая летопись по списку И.Н. Царского, Полное собрание русских летописей 39, Москва 1994, 89; Симеоновская летопись, Полное собрание русских летописей 18, Москва 2007, 72; Московский летописный свод конц̧а XV в., Полное собрание русских летописей 25, Москва - Ленинград 1949, 144; Вологодско-Пермская летопись, Полное собрание русских летописей 26, Москва - Ленинград 1959, 88; Никаноровская летопись, Полное собрание русских летописей 27, Москва - Ленинград 1962, 48.

49 Послание митрополита Фотия во Псков против стригольников (и по другим вопросам), w: Н.А. Казакова - И.С. Лурье, Антифеодальные еретические движения на Руси XIV-начала XVI в., Москва - Ленинград 1955, 249. Рor. Батунский, Россия, s. 97.

${ }^{50}$ Львовская летопись, s. 251.

${ }^{51}$ История о Казанском иарстве (Казанский Летописеи), Полное собрание русских летописей 19, Санкт-Петербург 1903, 146.

${ }^{52}$ Сочинения князя Курбского XXVI, ред. Г.З. Кунцевич, t. 1: Сочинения оригинальные, Русская Историческая Библиотека 31, Санкт-Петербург 1914, kol. 473. 
artykułu, ograniczymy się tutaj jedynie do przytoczenia kilku wybranych przykładów. I tak, dla autora Stowa o idolach, tworzącego prawdopodobnie jeszcze w XII stuleciu, Mahomet jest przede wszystkim pogańskim kapłanem Saracenów (Мамєа, проклятаго срациньскаго жерща) $)^{53}$. O krok dalej idą twórcy Opowieści o pobojowisku Mamajowym, XV-wiecznej literackiej relacji z bitwy na Kulikowym Polu (1380). W ich ujęciu muzułmański prorok, wymieniony obok Peruna, Heraklita (sic!) i Chorsa, staje się jednym z bogów, których rzekomo czcili Mongołowie/Tatarzy (Мамаи жє вид Ввъ пов Ва, свою, нача призывати воги своя: Перуна, Иракаия, Салавата, Хчреа и великого посовника Махъмета $)^{54}$.

Nierzadkie są też u autorów staroruskich skojarzenia z siłami piekielnymi. Dla przykładu: w niewielkim utworze historiograficznym, zachowanym na kartach rękopisu РГБ, Муз. собр. 3841 (XVI w.), Mahometa nazwano wprost synem szatana (0каанныи же злу пророк их МагмєА, взяв силу и крєпость у отца своєго сатаны) ${ }^{55}$. W treści Wielkich Mineji Lekcyjnych, skompilowanych w połowie XVI w., natrafić możemy na stwierdzenie, że nasz bohater nie był Bożym prorokiem ani apostołem, lecz dowódcą armii szatańskiej (Махмету ли, иже ньсть от Бога, ни Божий пророкъ, ни апостолъ, но сатанина полка полковод, єщъ сый) ${ }^{56}$. Dość powszechnym zjawiskiem jest też postrzeganie założyciela islamu jako zwiastuna Antychrysta. Został on zaprezentowany w ten sposób np. we wspomnianej wyżej zachodnioruskiej redakcji Chronografu Ruskiego (При сємъ Бысть Прєд, течд антихристовъ, Ажепророкъ сквєрный Бахмєтъ $)^{57}$. Niezwykle interesujący passus odnajdujemy też w jednym z pism Zenobiusza z Otyni ( $\dagger 1568)$. Autor ten, polemizując z ruchami heterodoksyjnymi, rozpowszechnionymi na Rusi w jego czasach, sugeruje, iż w dziejach ludzkości było tylko trzech groźnych poprzedników Antychrysta: Mahomet, który siał zamęt na Wschodzie, Marcin Niemiec [tj. Luter], który rozniecił ogień sporów religijnych na Zachodzie oraz Teodozy Kosy († po 1575), rozsiewający herezję na Litwie (востокъ вєсь разврдти Бахмєтомв, здпадъ же Мартиномz н'вмчиномz, Аитву же Косымz, предпутіє творя антихристу пред, отечами его - Бахметомz и Мартиномъ и Косымz) $)^{58}$.

${ }^{53}$ Е.В. Аничков, Язычество и Древняя Русь, Санкт-Петербург 1914, 384. Рог. Батунский, Россия, s. 46.

${ }^{54}$ Памятники Куликовского изикла, Х, ред. Б.А. Рыбаков - В.А. Кучкин, Санкт-Петербург 1998, 247. Рог. Батунский, Россия, s. 63-64; В.Н. Рудаков, Монголо-татары глазами древнерусских книжников середины XIII-XV вв., Москва 2014, 158.

${ }_{55}^{5}$ М.Н. Тихомиров, Русское летописание, Москва 1979, 161; Батунский, Россия, s. 94.

${ }^{56}$ Мучение святого и прославленного великомученика Христова Гергия Нового, пострадавшего в болгарском городе Средие, ред. Н.Ф. Дробленковая, w: Библиотека литературы Древней Руси, ред. Д.С. Лихачев - Л.А. Дмитриев - А.А. Алексеев - Н.В. Понырко, t. 12: XVI век, Санкт-Петербург 2003, 260.

${ }^{57}$ Русский хронограф. Хронограф Западнорусской редакиии, s. 122.

58 Зиновий Отенский, Истинь показание. К вопросивщем о новом учении, Казань 1863 , 48-49. Рor. Батунский, Россия, s. 87. 
Niekiedy w tekstach staroruskich natrafić możemy na stwierdzenia, noszące wszelkie znamiona inwektywy. Dla przykładu: w Paleji komentowanej z XIV w., czytamy, iż Agareni wierzą w żydowskiego niewolnika Mahometa (Агаране, в Бровдвше въ жидовьскаго хлдпд Бохмита) ${ }^{59}$. Nadspodziewanie rzadko $\mathrm{w}$ utworach $\mathrm{z}$ interesującego nas tu obszaru muzułmański prorok ukazywany jest natomiast jako założyciel nowej, odrębnej od chrześcijaństwa i judaizmu, religii monoteistycznej. Za jeden z nielicznych zabytków, zawierających tego rodzaju przekaz, uznać możemy zachodnioruską redakcję Chronografu Ruskiego. Odnajdujemy w niej narrację o Osmanie (1258-1324), eponimicznym protoplaście Turków Osmańskich i jego konwersji na islam, w której czytamy o tym, iż „przyjął on wiarę saraceńską, założoną przez Mahometa (приялz с ними в вру Сараценску, отъ Махомета устАвлєнУЮ)" $"$ "60.

Reasumując, można przyjąć, iż na kartach rękopisu PHБ, F.IV.151 zamieszczono dwa wyobrażenia ikonograficzne Mahometa (fol. 677 i 682). Ich twórcy nawiązali do głęboko zakorzenionej w kulturze staroruskiej, przejętej z literatury bizantyńskiej, tradycji ukazywania założyciela islamu jako fałszywego proroka/herezjarchy. Jego wizerunki korespondują też z wymową ideową tekstu W Бохмитє ерєтиц' $(O$ Bohmicie heretyku), który ilustruja.

\author{
ONE OF THE HERESIARCHS? \\ ICONOGRAPHIC REPRESENTATIONS OF MUHAMMAD \\ IN THE PHБ, F.IV.151 MANUSCRIPT \\ IN THE CONTEXT OF THE OLD RUSSIAN NARRATIVES ABOUT HIM
}

(Summary)

The РНБ, F.IV.151 manuscript is the third volume of a richly illustrated historiographical compilation (so-called Лицевой летописньй свод - Illustrated Chronicle of Ivan the Terrible), which was prepared in one copy for tsar Ivan IV the Terrible in 1568-1576 and represents the development of the Russian state on the broad background of universal history. The aforementioned manuscript, which contains a description of the history of the Roman Empire and then the Byzantine Empire between the seventies of the $1^{\text {st }}$ century A.D and 919, includes also an extensive sequence devoted to Muhammad (W Бохмитє єрєтиц $\mathrm{t})$, derived from the Old Church Slavonic translation of the chronicle by George the Monk (Hamartolus). It is accompanied by two miniatures showing the representation of

\footnotetext{
${ }^{59}$ Палея Толковая, ред. А. Камчатнов, Москва 2002, 183. Por. Батунский, Россия, s. 44.

${ }^{60}$ Русский хронограф. Хронограф Западнорусской редакиии, s. 233.
} 
the founder of Islam. He was shown in an almost identical manner as the creators of earlier heterodox trends, such as Arius or Nestorius. These images therefore become a part of the tendency to perceive Muhammad as a heresiarch, a false prophet, and the religion he created as one of the heresies within Christianity, which is also typical of the Old Russian literature.

Key words: Muhammad, Islam, Byzantine sources, Old Russian Literature, Illustrated Chronicle of Ivan the Terrible (Лищевой летописный свод).

Słowa kluczowe: Mahomet, islam, źródła bizantyńskie, literatura staroruska, Iluminowany zwód latopisarski (Лицевой летописный свод).

\section{BIBLIOGRAFIA}

\section{Źródła}

DionizJusz z Furny, Hermeneia czyli objaśnienie sztuki malarskiej, tłum. I. Kania, red. M. Smorąg Różycka, Kraków 2003.

Georgius Monachus, Chronicon, ed. C. de Boor, t. 2, Leipzig 1904.

Johannes Damascenus, Liber de haeresibus, ed. B. Kotter, w: Die Schriften des Johannes von Damaskos, t. 4, PTS 22, Berlin - New York 1981, 19-67, thum. A. Zhyrkova: Jan Damasceński, O herezjach, ŹMT 59, Kraków 2011.

Syntagma XIV titulorum sine scholiis secundum versionem Palaeo-Slovenicam, adjecto textu Graeco e vetustissimis codicibus manuscriptis exarato, ed. V.N Beneševič, t. 1, Petropoli 1906.

Zakonopravilo or the Nomocanon of Saint Sava. The Ilovica Manuscript from 1262. Photoprint reproduction, ed. and appendices written by M.M. Petrović, Beograd 1991.

Вологодско-Пермская летопись, Полное собрание русских летописей 26, Москва Ленинград 1959.

Зиновий Отенский, Истины показание. К вопросивщем о новом учении, Казань 1863.

История о Казанском иарстве (Казанский Летописеи), Полное собрание русских летописей 19, Санкт-Петербург 1903.

Книгы временыя и образныя Георгия Мниха. Хроника Георгия Амартола в древнем славянорусском переводе. Текст, исследование и словарь, ред. В.М. Истрин, t. 1, Петроград 1920.

Летописеи Еллинский и Римский, ред. О.В. Творогов, t. 1, Санкт-Петербург 1999.

Летописный сборник, именуемый Патриарщею или Никоновскою летописью, Полное собрание русских летописей 9, Москва 2000.

Летопись по Воскресенскому списку, Полное собрание русских летописей 7, СанктПетербург 1856.

Лицевой летописный свод XVI в. Всемирная история, ред. Х.Х. Мустафин, t. 6-9, Москва 2014.

Львовская летопись, Полное собрание русских летописей 20/1, Санкт-Петербург 1910.

Московский летописный свод кониа $X V$ в., Полное собрание русских летописей 25 , Москва - Ленинград 1949.

Мучение святого и прославленного великомученика Христова Гергия Нового, пострадавщего в болгарском городе Средие, ред. Н.Ф. Дробленковая, w: 
Библиотека литературы Древней Руси, ред. Д.С. Лихачев - Л.А. Дмитриев А.А. Алексеев - Н.В. Понырко, t. 12: XVI век, Санкт-Петербург 2003, 257-270.

Никаноровская летопись, Полное собрание русских летописей 27, Москва Ленинград 1962.

Палея Толковая, ред. А. Камчатнов, Москва 2002.

Памятники Куликовского ичикла, ред. Б.А. Рыбаков - В.А. Кучкин, Санкт-Петербург 1998.

Послание митрополита Фотия во Псков против стригольников (и по другим вопросам), w: Н.А. Казакова - И.С. Лурье, Антифеодальные еретические движения на Руси XIV - начала XVI в., Москва - Ленинград 1955, 247-251.

Рогожский хронограф: текст, ред. Т.В. Анисимова, w: Летописи и хроники. Новые исследования. 2009-2010, ред. О.Л. Новикова, Москва - Санкт-Петербург 2010, 102-161.

Русский хронограф. Хронограф Западнорусской редакции, Полное собрание русских летописей 22/2, Петроград 1914.

Симеоновская летопись, Полное собрание русских летописей 18, Москва 2007.

Софийская первая летопись, Полное собрание русских летописей 5, СанктПетербург 1851.

Софийская первая летопись по списку И.Н. Царского, Полное собрание русских летописей 39, Москва 1994.

Сочинения князя Курбского, ред. Г.З. Кунцевич, t. 1: Сочинения оригинальные, Русская Историческая Библиотека 31, Санкт-Петербург 1914.

\section{Opracowania}

Baнкоu A., The Monk Encounters the Prophet. The Story of the Encounter between Monk Bahìra and Muhammad as it is Recorded in the Syriac Manuscript of Mardain 259/2, „Cultural and Religious Studies” 3 (2015) nr 6, 349-357.

Bahkou A., The Story of the Encounter between Monk Bahīra and Muhammad as it is Recorded in the Syriac Manuscript of Mardain 259/2: „, The Monk Encounters the Prophet", Lewiston 2017.

Brzozowska Z.A., Махметъ, Мухуметъ, Моамедъ, Бохмитъ. Formy imienia Mahometa $w$ średniowiecznych tekstach ruskich (XI-XVI w.) i ich pochodzenie, „Die Welt der Slaven. Sammelbände" [w druku].

Bushkovitch P., Orthodoxy and Islam in Russia 988-1725, w: Religion und Integration im Moskauer Russland. Konzepte und Praktiken, Potentiale und Grenzen 14.-17. Jahrhundert, hrsg. von L. Steindorff, Forschungen zur osteuropäischen Geschichte 76, Wiesbaden 2010, 117-143.

CHekin L.S., The Godless Ishmaelites: The Image of the Steppe in Eleventh to Thirteenth Century Rus', „Russian History” 19 (1992) nr 1, 9-28.

Christian-Muslim Relations. A Bibliographical History, ed. D. Thomas - B. Roggema, vol. 1: 600-900, History of Christian-Muslim Relations 11, Leiden - Boston 2009.

GERÖ S., The Legend of the Monk Bahīrā, the Cult of the Cross and Iconoclasm, w: La Syrie de Byzance à l'Islam: VII'-VIII ${ }^{e}$ siècles, Actes du Colloque international „De Byzance à l'Islam", Lyon - Maison de l'Orient Méditerranéen, Paris - Institut du Monde Arabe, 11-15 Septembre 1990, publ. par P. Canivet - J.-P. Rey-Coquais, Publications de l'Institut Français de Damas 137, Damas 1992, 47-57.

Grala H., Wygrać klęskę: pamięć „, wielkiej bitwy” w oficjalnej narracji moskiewskiej (XVI w.), w: Bitwa pod Orsza, red. M. Nagielski, Warszawa 2016, 227-242. 
HanaK W.K., The Impact of Byzantine Imperial Thought upon Vladimirian-Jaroslavian Russia, „Byzantine Studies/Études Byzantines” 8-12 (1981-1985), 117-129.

Hunger H., Die hochsprachliche profane Literatur der Byzantiner, Bd. 1: Philosophie, Rhetorik, Epistolographie, Geschichtsschreibung, Geographie, München 1978.

Maksimovich K., Byzantine Law in Old Slavonic Translations and the Nomocanon of Methodius, „Byzantinoslavica” 65 (2007) 9-18.

Miklas H., Zur kirchenslavischen Überlieferung der Häresiengeschichte des Johannes von Damaskus, „Monumenta Linguae Slavicae” 15 (1981) 323-387.

Petrović M.M., Saint Sava's Zakonopravilo on the Teachings of Muhammed, Belgrade 1997.

Popova O.S., Altrussische Buchmalerei 11. bis Anfang 16. Jahrhundert, Leningrad 1984.

Prodić S., Knjiga 'O jeresima' prepodobnog Jovana Damaskina kao 61. poglavlje sarajevskog rukopisa 'Zakonopravila'svetog Save Srpskog, Šibenik 2016.

Roggema B., The Legend of Sergius Bahīrā. Eastern Christians Apologies and Apokalyptic in Response to Islam, Leiden - Boston 2009.

Średniowieczne herezje dualistyczne na Bałkanach. Źródła słowiańskie, red. G. Minczew - M. Skowronek - J.M. Wolski, Series Ceranea 1, Łódź 2015.

Tradigo A., Ikony i święci prawosławni, tłum. E. Maciszewska, Warszawa 2011.

Walter C., Sztuka i obrzqdek Kościoła bizantyńskiego, tłum. K. Malcharek, Warszawa 1992.

Wolińska T., Arabowie, Agareni, Izmailici, Saraceni. Kilka uwag na temat nazewnictwa, w: Bizancjum i Arabowie. Spotkanie cywilizacji. VI-VIII w., red. T. Wolińska - P. Filipczak, Warszawa 2015, 31-46.

Wolińska T., Arabs, (H)agarenes, Ishmaelites, Saracens - a Few Remarks about Naming, w: Byzantium and the Arabs: the Encounter of Civilizations from Sixth to Mid-Eighth Century, ed. T. Wolińska - P. Filipczak, Byzantina Lodziensia 22, Łódź 2015, 22-37.

Амосов А.А., Лицевой летописный свод Ивана Грозного. Комплексное кодикологическое исследование, Москва 1998.

Аничков Е.В., Язычество и Древняя Русь, Санкт-Петербург 1914.

Арциховский А.В., Древнерусские миниатюры как исторический источник, Москва 1944.

БАТунский М.А., Россия и ислам, t. 1, Москва 2003.

ВАсильевский В.Г. - Никитин П.В., Сказания о 42 Аморийских мучениках и иеековная служба им, Mémoires de l'Académie Impériale des Sciences de St.-Pétersbourg, VIII ${ }^{\mathrm{e}}$ serie: Classe historico-philologique VII/2, St.-Pétersbourg 1905.

Зуьов Н.И., Заметки по поводу этнонима сарацины в некоторых древнерусских памятниках, w: Етнолингвистичка проучавања српског и других славенских језика. У част академика Светлане Толстој: зборник радова, уред. П. Пипер Љ. Раденковић, Београд 2008, 163-171.

Клосс Б.М., Летописный свод лищевой, w: Словарь книжников и книжности Древней Руси (вторая половина XIV-XVI в.), ред. Д.С. Лихачев, t. 2, Ленинград 1989, 30-32.

Клосс Б.М., Никоновский свод и русские летописи XVI-XVII вв., Москва 1980.

Лицевой летописный свод XVI в. Методика описания и изучения разрозненного летописного комплекса, ред. Е.А. Белоконь - В.В. Морозов - С.А. Морозов, Москва 2003. 
Лушников А.А., Панарион Епифания Кипрского и восприятие язычества в историософских взглядах древнерусских книжников XI-XIV вв., „Вестник Самарского университета. История, педагогика, филология” 7 (2015) 95-100.

МАксимович К.А., Древнерусская Ефремовская кормчая ХІІ в.: локализащия перевода в связи с историей текста, w: Лингвистическое источниковедение и история русского языка (2004-2005), Москва 2006, 102-113.

Морозов В.В., Лицевой свод в контексте отечественного летописания XVI в., Москва 2005.

Морозов В.В., От Никоновской летописи к Лицевому летописному своду. Развитие жанра и эволющия кониепции, „Труды отдела древнерусской литературы” 44 (1990) 246-268.

ПодОБЕДова О.И., Миниатюры русских исторических рукописей, Москва 1965.

Рудаков В.Н., Монголо-татары глазами древнерусских книжников серединь ХІІІ- XV вв., Москва 2014.

Творогов О.В., О составе и источниках хронографических статей Лищевого свода, „Труды Отдела древнерусской литературы” 28 (1974) 353-364.

Тихомиров М.Н., Русское летописание, Москва 1979.

Ульянов О.Г., Изучение семантики древнерусской миниатюры, w: Макариевские чтения, t. 4.2: Почитание святых на Руси, Можайск 1996, 108-119.

Черный В.Д., Некоторые особенности обозначения исторической среды в миниатюрах лицевого летописного свода XVI в. (география, топография, архитектура), w: Государственные музеи Московского Кремля. Материаль и исследования. Новые атрибуичии, t. 5, Москва 1987, 68-78.

ЩАпов Я.Н., Византийское и южнославянское правовое наследие на Руси в XI-ХІІІ в., Москва 1978.

ЩАПов Я.Н., Номоканон Иоанна Схоластика и Синтагма 14 титулов у Славян в IX-X в8., w: Beiträge zur byzantinischen Geschichte im 9.-11. Jahrhundert, hrsg. von V. Vavřinek, Praga 1978, 387-411. 


\section{ANEKS}

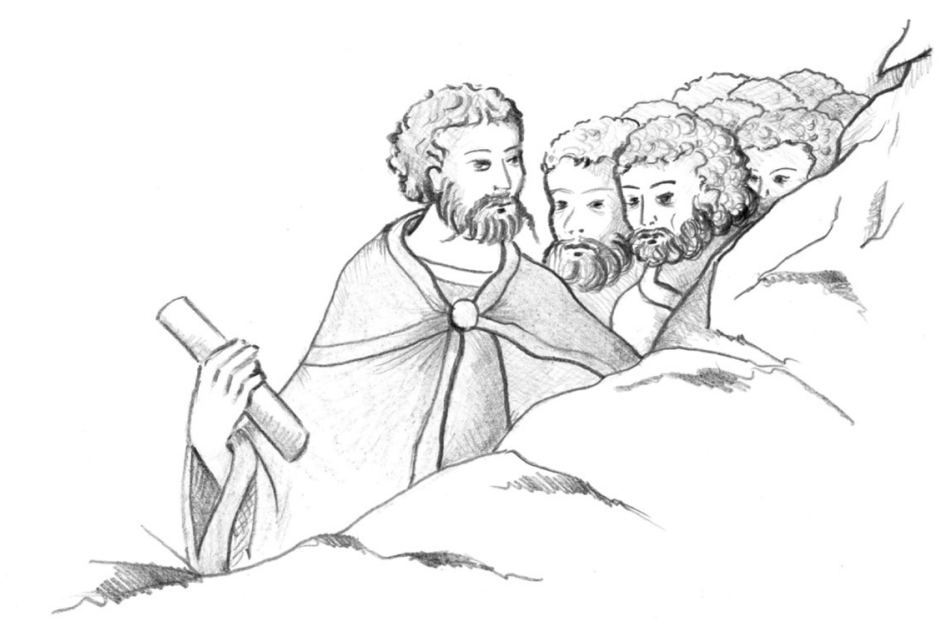

Rys. 1. Mahomet w gronie swoich uczniów. Fragment miniatury z rękopisu РНБ, F.IV.151 (fol. 677). Odrys: E. Myślińska-Brzozowska.

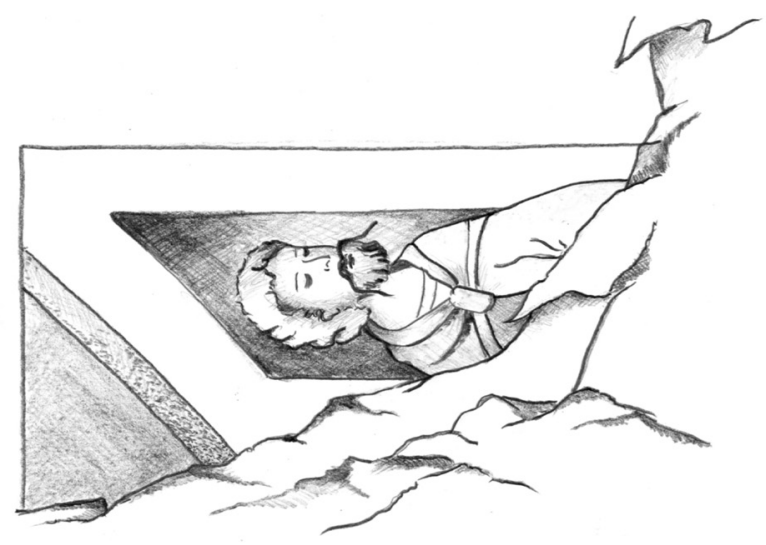

Rys. 2. Mahomet w grobie. Fragment miniatury z rękopisu PНБ, F.IV.151 (fol. 682). Odrys: E. Myślińska-Brzozowska. 
